\title{
Outcome of preoperative oral sildenafil in patients with pulmonary hypertension after mitral valve replacement.
}

1. MBBS, FCPS (Cardiac Surgery) Associate Professor Cardiac Surgery

Faisalabad Institute of Cardiology, Faisalabad.

2. MBBS, FCPS (Paediatric Medicine), FCPS (Paediatric Cardiology) Assistant Professor Paeds Cardiology

Faisalabad Institute of Cardiology, Faisalabad.

3. B.Sc, MBBS

Resident MS Cardiac Surgery Faisalabad Institute of Cardiology, Faisalabad.

Correspondence Address:

Dr. Shuja Tahir

Department of Cardiac Surgery

Faisalabad Institute of Cardiology,

Faisalabad.

drshuja192@hotmail.com

Article received on:

03/09/2020

Accepted for publication:

$03 / 12 / 2020$

\section{Shahbaz Ahmad Khilji', Abdul Razzaq Mughal ${ }^{2}$, Shuja Tahir ${ }^{3}$}

ABSTRACT... Objective: To determine the role of preoperative administration of sildenafil on outcome of patients having pulmonary hypertension with mitral valve disease undergoing mitral valve replacement surgery. Study Design: Randomized Control Trial. Setting: Department of Cardiac Surgery, Faisalabad Institute of Cardiology, Faisalabad. Period: June 2018 to June 2020. Material \& Methods: A total of 310 patients with mitral valve disease who underwent mitral valve replacement were included. The patients were divided into a control group of 155 , who were not administered oral sildenafil, and a study group of 155 who received oral sildenafil preoperatively. TVPG, LVEF and NYHA class were recorded preoperatively and postoperatively to compare outcome. Results: In the study group, postoperative LVEFs and NYHA class were not statistically significant in both groups while postoperative TVPG was significantly lower in study group as compare to control group and is statistically significant $(P<0.001)$. Conclusion: Our study concludes that oral administration of sildenafil preoperatively can be used as an effective treatment module to reduce pulmonary artery pressure in patients with pulmonary hypertension undergoing mitral valve replacement surgery and hence improves post-operative outcome.

Key words:

Left Ventricular Ejection Fraction, Mitral Valve Replacement, Mitral Valve Disease, Pulmonary Hypertension, Right Ventricular Failure, Sildenafil.

Article Citation: Khilji SA, Mughal AR, Tahir S. Outcome of preoperative oral sildenafil in patients with pulmonary hypertension after mitral valve replacement. Professional Med J 2021; 28(2):224-228.

https://doi.org/10.29309/TPMJ/2021.28.02.6250

\section{INTRODUCTION}

Increase in pulmonary vascular resistance due to mitral valve disease with pulmonary hypertension leads to right ventricular failure and mortality. ${ }^{1,2}$ Pulmonary hypertension is defined as an increase of the mean pulmonary arterial pressure more than $25 \mathrm{mmHg}$ at rest. ${ }^{3,4}$ Pulmonary hypertension affects all patients having mitral valve disease. ${ }^{5}$ Mitral valve disease increases left atrial pressures leading to potentially reversible increase in pulmonary pressures which in turn causes vascular injury along with remodeling of vessels results in right ventricular dysfunction. ${ }^{6}$ Pulmonary vascular resistance can be lowered by enhancing cyclic adenosine monophosphate (cAMP) using Beta agonist or phosphodiesterase inhibitors. ${ }^{2,7}$ In preoperative management of pulmonary hypertension, oral sildenafil is found very effective as it is a selective inhibitor of isoform 5 phosphodiestrase enzyme which increases in cyclic guanosine monophosphate
(cGMP) levels. ${ }^{8,9}$ Sildenafil can also be used to manage secondary pulmonary hypertension in perioperative period in patients undergoing open heart surgeries. ${ }^{10}$ There are fewer studies on the use of oral sildenafil ragarding preoperative management of pulmonary hypertension with mitral valve disease. ${ }^{11}$ This study was planned to evaluate the efficacy of preoperative oral sildenafil on post-operative pulmonary hypertension after mitral valve replacement surgery.

\section{MATERIAL \& METHODS}

This Randomized control trial was conducted at Department of Cardiac Surgery, Faisalabad Institute of Cardiology for two years from June 2018 to June 2020. The sample size was 310 patients (155 in each group).

\section{SAMPLE SELECTION Inclusion Criteria}

- Patients of both gender and age ranging from 
15-65 years.

- Patients with isolated mitral stenosis

- Rheumatic mixed lesions with predominant mitral stenosis

- Patients with moderate to severe pulmonary hypertension (Mean PAP $\geq 40 \mathrm{mmHg}$ )

\section{Exclusion Criteria}

- Patients with Right heart failure

- Patients with moribund preoperative state

- Patients having endocarditis and concomitant aortic valve disease

- Patients with coronary artery disease, EF $<45 \%$

- Patients with previous cardiac surgery

- Patients with preoperative multiorgan disease

After institutional ethical review committee approval, informed consent was taken. Three hundred and ten patients were enrolled who were scheduled for mitral valve replacement with moderate to severe pulmonary hypertension having tricuspid valve pressure gradient (TVPG) greater than $40 \mathrm{~mm}$ of $\mathrm{Hg}$ on preoperative transthoracic echo and were admitted through out-patient department. Clinical examination done in each case along with echocardiography, X-ray chest, ECG and routine laboratory investigation. Two groups were formed depending upon preoperative oral sildenafil administration. Study group consisted of 155 patients who received oral sildenafil (25mg thrice a day for two days preoperatively) and control group comprised of 155 patients who did not. Postoperative TVPG, LVEF and NYHA class were recorded.
Mitral valve replacement was done through median sternotomy. After aortic and bicaval venous cannulation, cardiopulmonary bypass was established. Cold cardioplegia administered for myocardial protection and heart to stop. After left atrial atriotomy, mitral valve excised with or without preservation of posterior mitral leaflet and is replaced with mechanical or tissue valve according to patient's condition. Statistical analysis was done using IBM SPSS Statistics Version 26.

\section{RESULTS}

Mean age in control group was $39.68 \pm 10.347$ while in study group $41.03 \pm 13.047$. Male patients in control group were $69(44 \%)$ while in study group there were $60(38.7 \%)$ (Table-I). We noticed no statistically significant difference between LVEF and TVPG preoperatively in both groups (Table-III). Post-operative data showed significantly lower TVPG in study group (32.5 4 $\pm 9.038)$ than in control group (43.08 \pm 14.608$)$ which was highly statistically significant ( $p$-value $<.0001$ ) (Table-IV). There was no significant difference between two groups in terms of LVEF and NYHA class. However, 119(76.8\%) patients in study group were having NYHA class I postoperatively while in control group there were 110(71\%) (Table-II).

\section{DISCUSSION}

This study showed that administration of preoperative oral sildenafil reduces postoperative tricuspid valve pressure gradient and improves NYHA class after mitral valve replacement.

\begin{tabular}{|l|c|c|c|}
\hline \multicolumn{1}{|c|}{ Variable } & Control Group & Study Group & P-Value \\
\hline AGE (MEAN \pm SD) Years & $39.68 \pm 10.347$ & $41.03 \pm 13.047$ & 0.314 \\
\hline MALE SEX NUMER (\%) & $69(44 \%)$ & $60(38.7 \%)$ & 0.357 \\
\hline NYHA II & $91(58.7 \%)$ & $99(63.9 \%)$ & 0.414 \\
\hline NYHA III & $64(41.3 \%)$ & $56(36.1 \%)$ & \\
\hline
\end{tabular}

Table-I. Preoperative Data

\begin{tabular}{|l|l|l|l|}
\hline \multicolumn{1}{|c|}{ Variable } & \multicolumn{1}{|c|}{ Control Group } & \multicolumn{1}{c|}{ Study Group } & P-Value \\
\hline NYHA I & $110(71 \%)$ & $119(76.8 \%)$ & 0.301 \\
\hline NYHA II & $45(29 \%)$ & $36(23.2 \%)$ & \\
\hline
\end{tabular}

Table-II. Postoperative NYHA CLASS 


\begin{tabular}{|c|c|c|c|}
\hline Variable & Control Group & Study Group & P-Value \\
\hline LVEF & $58.13 \pm 4.940$ & $58.32 \pm 5.734$ & 0.750 \\
\hline TVPG & $51.57 \pm 17.345$ & $48.86 \pm 18.471$ & 0.183 \\
\hline
\end{tabular}

Table-III. Preoperative ECHO DATA

\begin{tabular}{|c|c|c|c|}
\hline Variable & Control Group & Study Group & P-Value \\
\hline LVEF & $59.10 \pm 3.488$ & $59.23 \pm 2.681$ & 0.715 \\
\hline TVPG & $43.08 \pm 14.608$ & $32.54 \pm 9.038$ & 0.0001 \\
\hline
\end{tabular}

Mitral valve disease is common cause of pulmonary hypertension which is associated with poor prognosis after mitral valve surgery. ${ }^{12,13}$ Increased pulmonary hypertension give rise to increase in left atrial pressure causing low cardiac output. ${ }^{14,15}$ As there are selective drugs for pulmonary vasculature, treatment of pulmonary hypertension has not been fully established. ${ }^{16,17}$ 5-phosphodiestrase inhibitors have proven clinical efficacy in management of pulmonary hypertension. ${ }^{18,19}$ Randomized controlled trials, by Shim et $\mathrm{al}^{10}$ and the other by Gandhi et $\mathrm{al}^{20}$ showed reduction in pulmonary hypertension and also systolic and mean arterial pressures. However, shim et al treated with single dose of sildenafil while Gandhi et al used 3 doses for 24 hour preoperatively. In a study by Ram et al, sildenafil demonstrates a favorable decreasing effect on pulmonary vascular pressure without systemic hypotension and ventilation-perfusion mismatch. ${ }^{21}$ With a dose as low as $25 \mathrm{mg}$, hemodynamical effects of sildenafil on pulmonary circulation could be achieved as demonstrated by Wilkens et al. ${ }^{22}$ In order to reduce pulmonary hypertension and to improve RV function before surgery we used oral sildenafil $25 \mathrm{mg}$ thrice a day over $24 \mathrm{~h}$. In our study NYHA class and pulmonary hypertension improves with the use of oral sildenafil in patients undergoing mitral valve replacement.

\section{CONCLUSION}

Preoperative administration of oral sildenafil in patients with pulmonary hypertension effectively reduces pulmonary hypertension and improves NYHA class after mitral valve replacement surgery. Copyright $\odot 03$ Dec, 2020.

\section{REFERENCES}

1. Han B, Wang Q. Study on the clinical efficacy of specific phosphodiesterase inhibitor in patients with pulmonary hypertension due to left heart disease. Exp Ther Med [Internet]. 2018/06/13. 2018 Aug; 16(2):1175-86. Available from: https://pubmed.ncbi. nlm.nih.gov/30112056.

2. Gandhi H, Shah B, Patel R, Toshani R, Pujara J, Kothari $J$, et al. Effect of preoperative oral sildenafil on severe pulmonary artery hypertension in patients undergoing mitral valve replacement. Indian J Pharmacol. 2014; 46(3):281-5.

3. Galiè N, Humbert M, Vachiery J-L, Gibbs S, Lang I, Torbicki A, et al. 2015 ESC/ERS Guidelines for the diagnosis and treatment of pulmonary hypertension: The Joint Task Force for the Diagnosis and Treatment of Pulmonary Hypertension of the European Society of Cardiology (ESC) and the European Respiratory Society (ERS): Endorsed by: Association for European Paediatric and Congenital Cardiology (AEPC), International Society for Heart and Lung Transplantation (ISHLT). Eur Heart J. 2016 Jan; 37(1):67-119.

4. Hoeper MM, Bogaard HJ, Condliffe R, Frantz R, Khanna $D$, Kurzyna $M$, et al. Definitions and diagnosis of pulmonary hypertension. J Am Coll Cardiol. $2013 \mathrm{Dec}$; 62(25 Suppl):D42-50.

5. Baumgartner H, Falk V, Bax JJ, De Bonis M, Hamm C, Holm PJ, et al. 2017 ESC/EACTS Guidelines for the management of valvular heart disease. Eur Heart $\mathrm{J}$. 2017 Sep; 38(36):2739-91.

6. Magne J, Pibarot P, Sengupta PP, Donal E, Rosenhek R, Lancellotti P. Pulmonary hypertension in valvular disease: A comprehensive review on pathophysiology to therapy from the HAVEC Group. JACC Cardiovasc Imaging. 2015 Jan; 8(1):83-99. 
7. Ushio M, Egi M, Wakabayashi J, Nishimura T, Miyatake $\mathrm{Y}$, Obata N, et al. Impact of Milrinone Administration in Adult Cardiac Surgery Patients: Updated MetaAnalysis. J Cardiothorac Vasc Anesth [Internet]. 2016 Dec 1; 30(6):1454-60. Available from: https://doi. org/10.1053/j.jvca.2016.07.027.

8. Shewale V, Jadhao M, Shah V, Raut C, Mishra P, Khandekar J. patients with severe pulmonary artery hypertension undergoing mitral valve. 2020; 08(04):279-84.

9. Ibrahim IM, Dokhan AL, Elsebaey RS, Abdellatif MG, Elsebaey RS, Abdellatif MG. Evaluation of the preoperative administration of sildenafil on operative and early postoperative outcome after mitral valve replacement in patients with pulmonary hypertension. Egypt Cardiothorac Surg [Internet]. 2020 Oct 1; 2(4 SE-Adult cardiac):148-54. Available from: https://journals.escts.net/ects/article/view/150.

10. Shim JK, Choi YS, Oh YJ, Kim DH, Hong YW, Kwak $Y L$. Effect of oral sildenafil citrate on intraoperative hemodynamics in patients with pulmonary hypertension undergoing valvular heart surgery. J Thorac Cardiovasc Surg. 2006 Dec; 132(6):1420-5.

11. Villanueva DLE, Agustin RD, Llanes EJ. Pre-Operative sildenafil for patients with pulmonary hypertension undergoing mitral valve surgery: A systematic review and meta-analysis. Cardiol Res. 2019 Dec; 10(6):369-77.

12. vanderMerwe J, Casselman F. Mitral valve replacementcurrent and future perspectives. Open J Cardiovasc Surg [Internet]. 2017 Jul 13;9:11790652177190231179065217719023. Available from: https://pubmed. ncbi.nlm.nih.gov/28757798.

13. Dolapoğlu A, Avcı E. Effect of peri-operative milrinone on pulmonary artery pressure in patients undergoing mitral valve replacement. J Surg Med. 2019; 3(10):71821.

14. Nguyen A, Holecko J, Essandoh M. Milrinone in adult cardiac surgery: More evidence is needed to support routine inhalation administration. J Cardiothorac Vasc Anesth [Internet]. 2019 Mar 1; 33(3):674-6. Available from: https://doi.org/10.1053/j.jvca.2018.10.015.
15. Maeder MT, Weber L, Buser M, Gerhard M, Haager PK, Maisano $F$, et al. Pulmonary hypertension in aortic and mitral valve disease [Internet]. Vol. 5, Frontiers in Cardiovascular Medicine. 2018. p. 40. Available from: https://www.frontiersin.org/article/10.3389/ fcvm.2018.00040.

16. Tang GHL, Cohen M, Dutta T, Undemir C. Afterload mismatch after transcatheter mitral valve repair with MitraClip for degenerative mitral regurgitation in acute cardiogenic shock. Catheter Cardiovasc Interv [Internet]. 2018 Sep 1; 92(3):E168-71. Available from: https://doi.org/10.1002/ccd.27019.

17. Sardo S, Osawa EA, Finco G, Gomes Galas FRB, de Almeida JP, Cutuli SL, et al. Nitric oxide in cardiac surgery: A meta-analysis of randomized controlled trials. J Cardiothorac Vasc Anesth [Internet]. 2018 Dec 1; 32(6):2512-9. Available from: https://doi. org/10.1053/j.jvca.2018.02.003.

18. Essandoh MK. Afterload mismatch after mitraclip implantation: The potential impact of pharmacologic support. J Cardiothorac Vasc Anesth. 2017 Apr; 31(2):702-6.

19. Bermejo J, Yotti R, García-Orta R, Sánchez-Fernández PL, Castaño M, Segovia-Cubero J, et al. Sildenafil for improving outcomes in patients with corrected valvular heart disease and persistent pulmonary hypertension: A multicenter, double-blind, randomized clinical trial. Eur Heart J. 2018 Apr; 39(15):1255-64.

20. Gandhi H, Shah B, Patel R, Toshani R, Pujara J, Kothari $\mathrm{J}$, et al. Effect of preoperative oral sildenafil on severe pulmonary artery hypertension in patients undergoing mitral valve replacement. Indian $J$ Pharmacol [Internet]. 2014; 46(3):281-5. Available from: https://pubmed.ncbi.nlm.nih.gov/24987174.

21. Ram E, Sternik L, Klempfner R, Eldar M, Goldenberg I, Peled $Y$, et al. Sildenafil for pulmonary hypertension in the early postoperative period after mitral valve surgery. J Cardiothorac Vasc Anesth [Internet]. 2019; 33(6):1648-56. Available from: http://www.sciencedirect. com/science/article/pii/S1053077018311807.

22. Wilkens $H$, Guth $A$, König J, Forestier N, Cremers $B$, Hennen $B$, et al. Effect of inhaled iloprost plus oral sildenafil in patients with primary pulmonary hypertension. Circulation. 2001 Sep; 104(11):1218-22. 


\section{AUTHORSHIP AND CONTRIBUTION DECLARATION}

\begin{tabular}{|c|c|l|l|}
\hline Sr. \# & Author(s) Full Name & \multicolumn{1}{|c|}{ Contribution to the paper } & Author(s) Signature \\
\hline 1 & Shahbaz Ahmad Khilji & $\begin{array}{l}\text { Main author, Chief surgeon, } \\
\text { Proof reading, Supervision of } \\
\text { whole process. } \\
\text { Author physician, Proof reading, } \\
\text { Collection of references. } \\
\text { Author surgeon, Literature } \\
\text { review, Data collector, Statistical } \\
\text { work. }\end{array}$ \\
\hline 3 & Shuja Tahir & Abdul Razzaq Mughal \\
\hline
\end{tabular}

